\title{
CONSERVING THE PAST THROUGH PLAY: EDUCATIONAL GAMING AND ANTI- LOOTING OUTREACH IN CAMBODIA
}

\author{
Damien Huffer \\ School of Archaeology and Anthropology, The Australian National University, Acton, 0200 ACT, Australia \\ Email: damien.huffer@gmail.com \\ Keywords: Cambodia, archaeology, heritage, looting, educational computer games
}

\begin{abstract}
According to Heritage Watch, a collaborative NGO based in Cambodia which is active in archaeological salvage work, village outreach, and education, the looting of archaeological sites in Cambodia has now reached "epic proportions." Current looting activities primarily involve Bronze Age and Iron Age (c. 3500-1500 BP) burial mounds located in northeastern provinces. Perceived economic incentive and coercion of local villagers by duplicitous "middle-men" seeking inflated profits from the black market, and an overall lack of awareness of the significance of these sites amongst both locals and foreign visitors, furthered by a lack of appreciation of the importance of accurate archaeological excavations for understanding the prehistoric past, fuel an active antiquities trade. New laws and outreach projects have begun to be implemented in recent years, many showing promise, yet the fight against looting in Cambodia remains an uphill battle, requiring further efforts which take full advantage of current technologies. This paper will describe one such project: an educational computer game called Looter! It will be made available in both Khmer and English, and will integrate 2D and 3D art and animation, up-to-date archaeological knowledge, and easily accessible game play formats. Through introductory and interstitial animated "cut-scenes" and two levels of game play, the player will not only begin to understand what is known about Cambodia's late prehistory, but will also comprehend the damage that looting does to all involved, and conversely, the benefits to be gained from scientifically sound excavation. The paper will discuss game development to date, its context, background and planned applications.
\end{abstract}

\section{INTRODUCTION}

In a recent exposé article in the Society for American Archaeology's trade journal, the Archaeological Record, Jennings and Rand point out that while "on the surface it looks like we are winning the fight against the market in illicit antiquities” (Jennings and Rand 2008: 28), continued action against the global antiquities trade is necessary.
Since the UNESCO Convention to prohibit the illicit trade in cultural property was drafted in 1970, there have been improvements in law enforcement, an increase in repatriation claims by countries, and the adoption of codes of ethics in relation to the trade by collectors, dealers, museums, and archaeologists. Yet, the pillaging of archaeological sites and museums for antiquities has only increased over the last four decades (Brodie and Luke 2006).

It is unfortunate that, like many other categories of illicit smuggling (e.g. wildlife poaching, arms trading, drug running), the process of providing and obtaining antiquities for worldwide black markets has moved increasingly underground. Looters in most areas today operate clandestinely at night or in remote areas, utilizing both low and high-tech means (from shovels to metal detectors), while the middlemen who buy artefacts look for new ways to falsify documents, obscure provenances, and by-pass customs and shipping agents (Brodie and Luke 2006; Renfrew 2000). In a larger sense, the antiquities trade (and owning antiquities) is still seen as novel, inconsequential or inexhaustible, with higher prices being driven by higher demand from wealthy international purchasers-to the point where Time Magazine dubbed antiquities "the hottest investment" in the fall of 2007 (Jennings and Rand 2008; Baugh 2007). Moreover, the high profile nature of "professional" collecting by multimillionaires and/or museums in knowing or unknowing violation of their ethical standards, however, masks the much more numerous and diffuse collection done by members of the general public, who either acquire their antiquities from dealers or middlemen or more frequently purchase them at auction, on-line, or as authentic or inauthentic souvenirs while on vacation (Jennings and Rand 2008; Lidington 2002; Politis 2002). Many claim to be driven by their "passion" for art history or archaeology, or an avocational interest (Brodie and Luke 2006), yet are, at best, duped by con artists, or at worst, active participants in the rapid destruction of the archaeological record.

Due to the diversity of stakeholders involved in the antiquities trade today and the socio-economic, cultural, and educational disparities often seen between those involved, effective countermeasures must be able to target 
and reach several different populations simultaneously. Some high profile museums and on-line distribution agencies, following embarrassing sting operations (e.g. Reyes and Lopez 2008), are beginning to refine their ethical codes and repatriate and/or provenance their acquisitions more efficiently in agreement with new laws. Additionally, literature, posters, archaeological education programs, on-the-ground workshops, and much more hands-on museum exhibits are now being implemented in various parts of the world, but mostly in wealthier countries (e.g. Moe 2000; Stone and Molyneaux 1994; Cordova-Gonzalez 2000; Shoup and Monteiro 2008) (Figs. 1, 2).

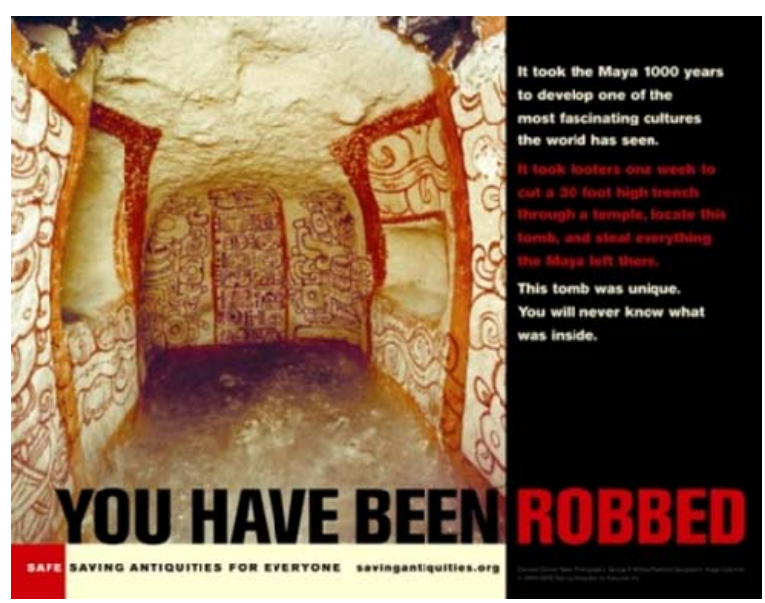

Figure 1. Looting awareness campaign winning entry from a student competition overseen by S.A.F.E. (Saving Antiquities For Everyone). Concept: Donna Yates. Photography: George F. Mobley/National Geographic Image Collection (c) 2006 SAFE/Saving Antiquities For Everyone, Inc.

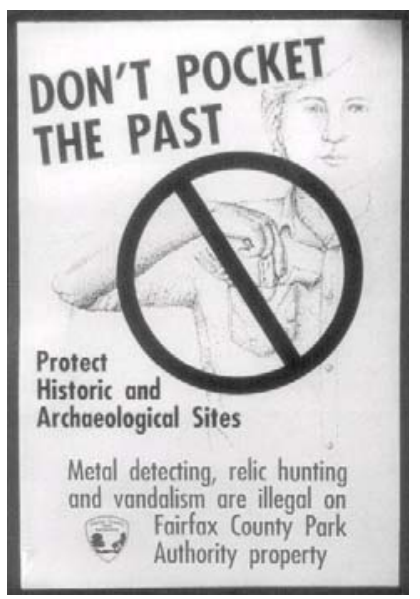

Figure 2. Anti-looting poster, Fairfax County Virginia, U.S.A. http://www.mcdonald.cam.ak.uk/projects/iarc/culturewithoutcon text/issue9/hicks.html. (Courtesy of Fairfax County Parks Authority, Virginia, USA).

Large-scale non-profit or non-governmental organizations such as S.A.F.E. (Saving Antiquities For Everyone), the U.S. National Park Service, and, within Cambodia itself, the NGO Heritage Watch (founded in 2003) con- tinue efforts to increase awareness and resource pooling amongst the general public and the archaeological community (Renfrew 2000; Knoll 1990). While these efforts are beginning to pay off, the fact that both looting and smuggling continues, even within Western countries where most effort has been directed, strongly suggests that new approaches and further advocacy are still necessary. This is especially crucial for under-represented areas, such as Southeast Asia, within which specific countries, such as Cambodia, remain prolific suppliers of international demand.

Because of the pressing nature and complex logistics of the looting crisis in Cambodia today, it is clear that all future attempts at finding solutions must be engaging, targeting both urban and rural locals and foreign visitors (all involved in supplying or purchasing looted antiquities), and most importantly, be memorable to those who use these media. Some researchers advocate taking a social marketing approach; i.e. running complex multinational campaigns primarily targeting the "average" Western collector, but often costing millions of dollars (Jennings and Rand 2008; Miller and Pitaluga 2000). This paper, however, will describe a more cost-effective, and arguably equally practicable, means of conveying an effective anti-looting message across the social spectrum in the form of an educational computer game. Creation of such "learning games" for advertising, social, environmental, and physical fitness awareness projects, and political campaigning have already shown much promise in changing attitudes and affecting behaviours (e.g. Bogost 2007). Regardless of subject, the successful educational game project does not operate in a vacuum, but rather best operates in tandem with other forms of outreach. The project described below represents the first such attempt at designing an educational game specifically for use in conjunction with anti-looting/heritage conservation programs in Southeast Asia. Before describing the project in detail, it is necessary to provide a background to both the archaeology of Cambodia and the nature of the looting crisis, as well as a general overview of the theory and logic behind the construction of learning games. Overall, this paper will discuss why "preserving the past through play" is a valid approach to mitigating heritage destruction; describing the Looter! educational gaming project as an example of this approach.

\section{ARCHAEOLOGY \& THE SCOPE OF LOOTING IN CAMBODIA}

\section{Cambodian Prehistory: An Overview}

Archaeological survey and research in Cambodia has a long history extending back to at least 1876 (Stark 2004: 89). Social and political upheaval during the Khmer Rouge regime (1975-1979), however, utterly curtailed scientific research and education, archaeological or otherwise (Clayton 1998). Because of this disruption, the publication and analysis of older sites, and the discovery, excavation, or salvaging of new ones, has only recently resumed. At the same time, this recent increase in ar- 
chaeological activity coincides with both the gravest overall threat to Cambodia's past yet encountered, as well as presenting opportunities to conserve it by restoring its image as something central to the cultural identities of present and future generations of Khmer. This must entail not only continued excavation and conservation of the temples of the Early Historic and Angkorian periods (e.g. Stark 1998), but also the still poorly understood prehistoric past (Fig. 3). Therefore, the section below will both summarize what is known of Cambodia's prehistory, as well as outline the scope and nature of the looting threat with an eye towards clarifying both what is at risk, and why heritage preservation outreach remains a necessity.

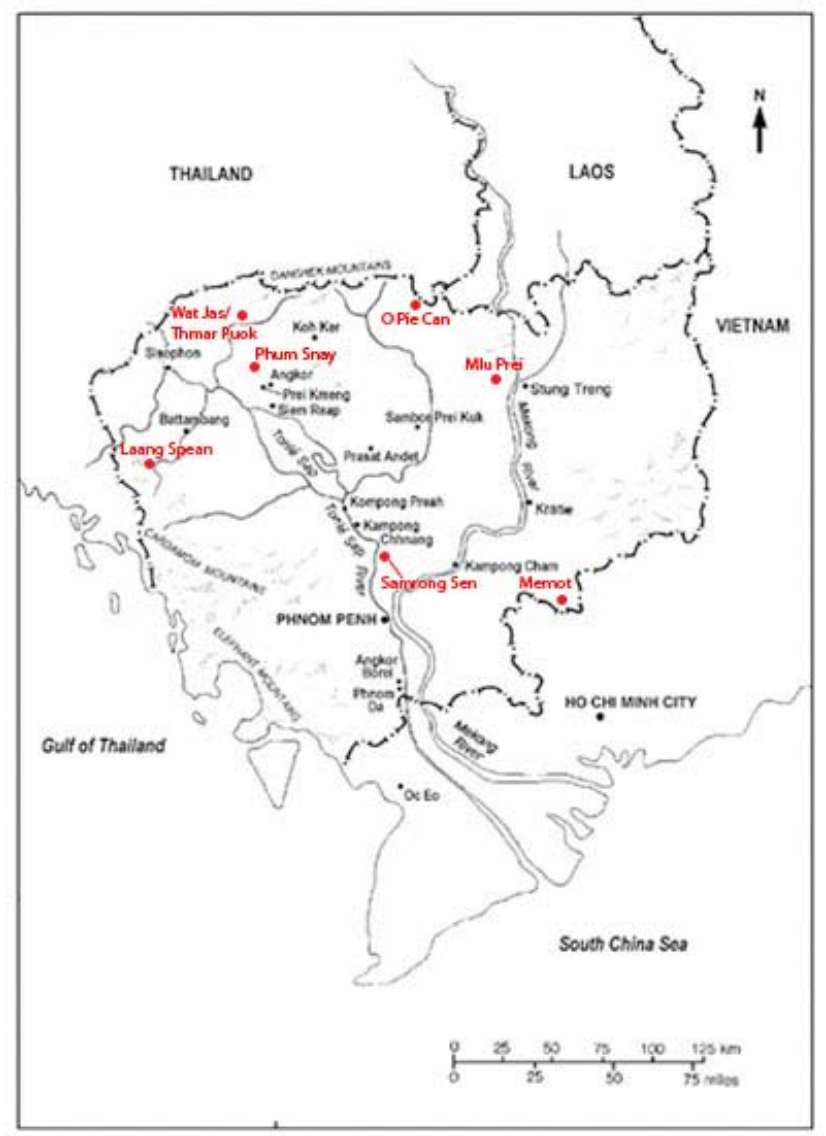

Figure 3. Map giving the approximate location of key prehistoric (in red) and historic (in black) period sites mentioned in the text. Original available in Dowling (1999).

Regarding Cambodia's earliest known prehistory, the lower stratigraphic level of Laang Spean dates to c. 8000 $\mathrm{BP}$, and is the only recorded "Hoabinhian" (c. 8000-5000 BP) site in Cambodia (Stark 2004). Its strata provide evidence of a broad subsistence base and stone tools characteristic of the Hoabinhian elsewhere in Southeast Asia, while its upper layers contain Cambodia's first pottery. Understanding of the Cambodian Neolithic is somewhat more detailed, although still hampered by an overall dearth of exploration. The continuity of some Hoabinhian lithic technologies and the addition of a few new artefact forms is observed (Stark 2004), although only a few Neolithic sites have received controlled excavation pre-1975. These include Laang Spean (Mourer 1977), Samrong Sen (Mansuy 1902), Phnom Laang (Carbonel \& Guth 1968), and the first discovery of settlements located inside circular earthen embankments at Memot and Krek (e.g. Dega 1999; Albrecht et al. 2001). After 1989, many more sites have come to archaeologists' attention. These include several more earthenwork sites within the Terres Rouges (Red Earth) region bordering southern Vietnam (e.g. Kbal Romeas, dated c. $5370 \pm 140 \mathrm{BP}$ ), which contain marine shells and ceramics but lack domestic plants or animals. Other, smaller, earthenwork sites in Kampong Cham and Ranttanakiri provinces have produced Neolithic materials. Regardless of their uncertain dates, it has been tentatively suggested to be ethno-archaeologically related to Kr'ung domestic materials in Ranttanakiri Province (Sophady 2002: 482). At all such "Neolithic" sites, flaked and polished stone tools (scrapers, adzes and axes), stone bracelets and typologically diverse, locally produced, pottery have continued to be found. Typologically, these materials have affinity with late Neolithic/early Bronze Age sites in Vietnam and Thailand, while Dega (2002) has dated rice chaff in ceramics from Krek 52 to c. 4300-2300 BP. The general material culture, including glass bangle fragments from Krek 52/62 (Dega 2002), suggests habitation from the Neolithic through to the Iron Age (c. 5000-1500 BP), however, soil conditions have ensured that no metal or human remains survive. The function of these sites also remains unclear; communal village enclosures, and livestock pens, or ritual centres have all been proposed (Stark 2004; Dega 2002). Due to the general remoteness of these sites and their lack of clear association with human remains which contain precious metals or jewellery, looting activity has been minimal to date, but may increase in future as cross-boarder commerce and tourism between Vietnam and Cambodia increases.

As with previous periods, our knowledge of later prehistory (i.e. Bronze and Iron Ages c. 3500-1500 BP) regionally within Southeast Asia is quite incomplete, with most sites coming from Thailand and northern Vietnam. Even though an archaeological comprehension of the technology, subsistence, social organization and trading networks of this time period within Cambodia itself is improving, it is far from solidified and, due in part to the prevalence of looting in the northwest, will require decades of further work. Ly (1999) describes work carried out at Samrong Sen in Kampong Chhom Province, which contains metal tools and jewellery above its Neolithic strata. Similar habitation sequences occur at some of the larger earthwork sites such as Krek and Memot (Dega 1999).

Levy (1943) was first to excavate late Bronze/early Iron Age sites in Mlu Prei province in the north, revealing many bronze and bronze/iron artefacts in domestic contexts. Higham (2002) and Stark (2004) describe survey and excavations at the nearby sites of O Yak, Long Prao, $\mathrm{O}$ Pie Can and O Nari in Ranttanakiri and Preah Vihear provinces. The diversity and continuity of metal, stone, 
and earthenware material culture demonstrates habitation from the Neolithic to the early Iron Age, with a few previously disturbed inhumations uncovered at $\mathrm{O}$ Yak. Salvage excavations at two major sites in the northwest provinces; namely, Phum Snay and Wat Jas, revealed extensive Iron Age cemeteries (c. 1500 BP) in direct association with domestic settlements, hearths, and refuse (O’Reilly, von den Driesch and Vouen 2006). Furthermore, skeletal analysis of some of these individuals, as well as two skeletons from the Iron Age site of Prei Khmeng (Chhem et al. 2004), is beginning to provide insights into the lives and deaths of individual people during this very little known era of Cambodia's past. When placed into larger archaeological contexts, everything from subsistence patterns to human migration, social organization, and funerary rituals can become illuminated through bio-archaeological investigations. Regretably, Phum Snay, Wat Jas, and even newly discovered Iron Age sites elsewhere (Chandara 2007; Albrecht 2007), were all almost completely looted before archaeologists could reach them, levelling further tragic blows to scientific comprehension of Cambodia's past.

\section{THE SCOPE OF THE LOOTING CRISIS}

It is probably safe to say that Cambodia, since 1953, has undergone the most dramatic and turbulent period in its 1,200 year history. The country has traversed a landscape that saw independence, war, complete social, economic and political upheaval, invasion by a foreign power, an international transitional authority and now political stability (O’Reilly 2007: 12).

Although such developments, and the poverty and social inequalities that tend to accompany such conflicts and transitions, are not unique to Cambodia, the many vestiges of its ancient past have attracted illicit smuggling since at least the 15th century, when Thai soldiers carried off bronze and basalt Angkorian statues, many of which were subsequently brought to Mandalay in Burma when Ayutthaya was overthrown (O'Reilly 2007). The looting of statuary from temple complexes continued during French colonial rule, peaking from the 1970 s to 1990 s during and after the Khmer Rouge regime, when monitoring was minimal and both sides were implicit (Net 1994). At least as recently as 1997, armed gangs of looters were dismantling more remote temple complexes such as Koh Ker and using video recording of their activities as marketing materials to Bangkok-based dealers (Anon 1992; Chaumeau 1997). Despite increased oversight by the Ministry of Interior's Heritage Police around the largest Angkorian monuments, increased tourism, and a new Memorandum of Understanding between Cambodia and the United States in 2003 (effectively banning legal import/export of historic, and recently late prehistoric, artefacts), very few undisturbed temples remain and few pieces of statuary are recovered and repatriated (International Council of Museums 2007).

As mentioned above, recent years have seen looting activity turn to late prehistoric sites throughout the country, primarily to recover the carnelian, gold, agate and glass jewellery contained in many Bronze and Iron Age graves (e.g. O’Reilly and Sytha 2001). Although this phenomenon has been recognized for some time (e.g. Thosarat 2001) and widely reported in the Cambodian press (e.g. Chandara 2007), both reports of new looting and official artefact seizures (usually of statuary) have continued apace, especially since 2000 . As most sites are either undocumented or unguarded, and enforcement of laws remains intermittent, the actual number of looting events needed to underpin this increase is likely to be substantially higher (O’Reilly 2007). A poignant example can be found in the survey/salvaging of 23 looted burial mounds in the vicinity of the Thmar Puok banana farm in Banteay Meanchay Province, one of which is Wat Jas (Fig. 4), dating to the Iron Age (c. 500 BC-AD 500) (Heritage Watch 2006). By the time archaeologists reached Wat Jas in particular, very few intact burials were recovered, with more than 1000 suggested from the density of discarded "utilitarian” bones and artefacts! No mortuary site yet known from Southeast Asia has greater than 800 recovered burials, especially not from one contemporaneous period. Ethnographic surveys indicate that between 50-200 locals (the poorer amongst them paying for permission to dig on others' property), armed with metal detectors and shovels, descended on these sites and dug numerous shafts up to three meters deep, quickly selling rarer artefacts recovered to visiting middlemen. Even in more intensively surveyed regions, such as Takeo province in the Southeast, similar looting events are increasing (Albrecht 2007; Stark and Griffin 2004).

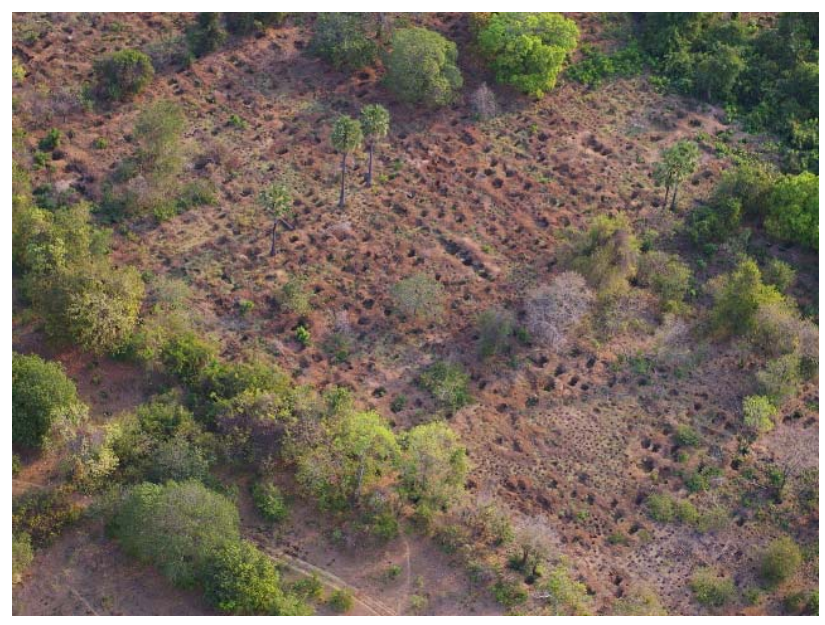

Figure 4. Aerial view of the field of looter's pits that was the Iron Age cemetery of Wat Jas, Banteay Meanchay Province, Cambodia (Courtesy of Dr. Dougald O'Reilly).

Three general categories of looting activity tend to occur worldwide; namely, "opportunistic" (accidental discovery of artefacts and opportunistic selling), "semiprofessional” (go-betweens who supplement their income by looting and selling to established contacts), and "professional” (armed gangs of individuals who loot for a living) (Parkes et al. 2006; Matsuda 1998). Whereas past acts of temple destruction have occurred due to armed professionals, most looting of prehistoric sites in Cambo- 
dia today is semi-professional, as defined above, driven by poverty, boredom or personal gain (Lor 2007; O’Reilly pers. comm.). Although most looted artefacts of high quality cross the boarder into the markets of Bangkok, Singapore and Ho Chi Minh City, many smaller items also circulate in urban Siem Reap and Phnom Penh, providing ample supply for souvenirs purchasing (Fig. 5).

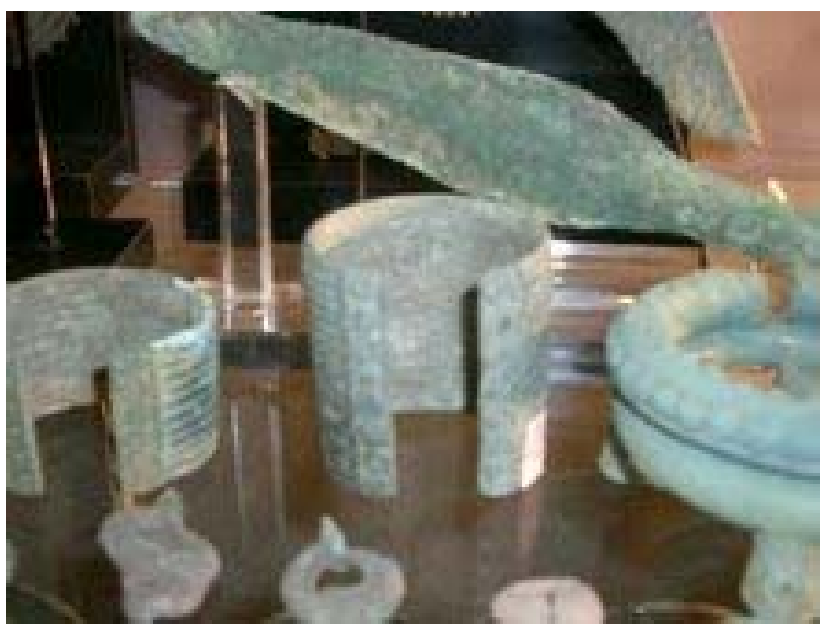

Figure 5. Iron weapons and jewelry for sale in a Phnom Penh antiquities stall (Courtesy of Dr. Kyle Latinis).

On a global scale, the growth of auction houses (e.g. Sotheby's) and on-line commerce (e.g. E-Bay) have seen a massive increase in antiquities sales, especially of smaller items, regardless of attempts to rely on users to monitor illicit activities. These sales are often undertaken with little stated concern for provenance by overseers, and in knowing violation of existing laws. Statements such as that in a recent Business Week article:

collectors don't need big bucks to get started ... opportunities still abound to get into the market before the door shuts tight (Anon. 2005)

can only fuel this trend, to which artefacts from Cambodia still contribute, despite a 1999 emergency ban imposed by the United States and the 2008 listing of Cambodia on the ICOM "Redbook" of antiquities (Heritage Watch 2008). In response, Heritage Watch and others have begun outreach efforts on several fronts, including village workshops, a hotline to report looting activity, community based "heritage patrols" to monitor select sites (with associated tourism and business management training), radio and television advertisements, and even a bilingual comic book; all crucial components of an eventual nationwide campaign.

To make this plan a reality, it is the author's contention that additional approaches to Cambodian archaeological outreach are warranted; ones which utilize technologies and methods not previously brought to bear. As will be demonstrated, educational gaming can help fill this void.

\section{PRESERVING THE PAST THROUGH PLAY: WHY A LEARNING GAME?}

In his classic work Homo ludens, Dutch anthropologist John Huizinga struggled with defining the relationship between concepts of "play" and "seriousness," noting that one can "play seriously," but that "seriousness does not seem to include the possibility of play," suggesting that play supersedes it, and can thus "help constitute social and cultural functions of great gravity .... including religion, politics and warfare.” (Huizinga 1955:26-28; Bogost 2007:55). Since then, especially since the 1970s as computational, digital, and online technologies began to flourish, a separate genera of "serious games" has emerged, seeking to incorporate the engaging elements of play (its memorability, interactivity, and immersive nature) into discussion and education about otherwise weighty or complicated topics. Abt (1970:9) defines them thus:

We are concerned with serious games in the sense that these games have an explicit and carefully thought-out educational purpose and are not intended to be played primarily for amusement, but that this doesn't mean they are not, or should not be entertaining.

Although commercial games in all their variety are not necessarily incapable of simulating or illuminating realworld events, serious games tend to be identified primarily by their approach to such topics. While institutions such as the Serious Games Initiative tend to define such games as those designed to support the positions or campaigns of companies, institutions, politicians or advertising agencies, more recently those games that persuade players to both learn about and potentially challenge commonly held misconceptions about realworld systems are being included. These are termed “persuasive games" by Bogost (2007). The persuasion referred to is different from the overt psychological coercion that keeps arcade game players playing (e.g. Loftus and Loftus 1983), but rather one that "makes arguments about the way systems work in the material world," in order to "alter or affect player opinion outside of the game...to move the player from the game world into the material world" (Bogost 2007:47). In other words, these are games that make effective use of process to illustrate or simulate the complex.

On a macro scale, Sutton-Smith (2001) defined seven "rhetorics of play," such as "progress" and "power," which define the broad cultural contexts that underlie the rules of games and what one intends to demonstrate with them. More relevant to discussions of the "power of play," however, is a recognition that rhetoric and design can be used to "unpack the rules of a particular game in a particular context” (Bogost 2007:54). A successful educational game, then, will be deliberately designed to operate within contextualized situations relevant to its audience; situations actively participated in, but with 
outcomes either ignored or taken for granted. How can educational games accomplish this? Game theorist James Gee (2003) identifies a four step process, in which the player probes the virtual/simulated world depicted in the game through their actions, reflects on the result and forms a hypothesis about its significance, reprobes the world with that hypothesis in mind to examine its effect, then treats that effect as feedback from the world in order to rethink their hypothesis. After all, "a game is not simply a text to be read, but an experience to be had" (Consalvo 2003: 173). Even those games in which certain end-game scenarios can be viewed as "negative" (i.e. avatar death, arrest, or, in the case of Looter!, the destruction of heritage and landscape), a player's ability to actively manipulate their own outcome makes all such knowledge gained a worthwhile experience.

Many scholars and game designers (e.g. Prensky 2001; Ruggill and McAllister 2008) continue to extol the virtues of well designed learning games as relatively cheap, efficient ways to illustrate complex subject matter, accommodate the differing attention spans and learning modes of both young and old (i.e. those with more vs. less exposure to communications technology), and even attract those with little to no previous gaming experience (such as children in developing countries), given appropriate delivery systems and context. Prensky (2001: 164) defines eight relatively binary categorizations useful for classifying a learning game. By his schema, Looter! will be "intrinsic" (i.e. content is an integral part of game structure), "tightly linked" (i.e. specifically constructed around a fixed set of content), "asynchronous" (i.e. turnbased, allowing players to make decisions at their own pace), "single-player," "session based" (i.e. "exist” only when a player is interacting with it), and will carefully balance recollection through "narrative" vs. action requiring "reflex." This combination of parameters has proven very amenable as logistical guidelines for conceptualizing the game's layout, building and testing a "proof-ofconcept” prototype, and securing initial funding.

\section{LOOTER! IN “REAL TIME”: ORIGINS, LOGISTICS, AND CURRENT PARAMETERS.}

As discussed above, there is a substantial theoretical background underpinning the use and development of educational gaming projects in general, and numerous excavation and outreach projects capitalizing on increasing Western and Khmer collaboration in particular. However, as also demonstrated, the threat posed by looting remains severe across Cambodia. Given the potential of learning games to serve as powerful outreach tools, the remainder of this paper will describe the origins, logistics, current conceptualization, and planned future uses of the Looter! educational gaming project.

Looter!'s story arch was inspired by Wrath of the Phantom Army, a comic book funded and distributed by Heritage Watch, in collaboration with local artists, editors and archaeologists, to significant success, especially in rural provinces. The game itself was first formulated in March 2006 after the author attended the 19th Annual
Indo-Pacific Prehistory Association conference, and was introduced to the diverse and pressing on-the-ground work of Heritage Watch. Initial brainstorming, design of a "proof-of-concept" prototype of the overall game engine and 1st level (utilizing the Director programming language), and creation of promotional materials, allowed major funding to be applied for (Fig. 6). While unsuccessful at first, thus forcing most expenses to be out of pocket, initial start-up funds were obtained from the University of Arizona's Center for Educational Resources in Culture, Language, and Literacy. The contacts made in these initial funding attempts, both within and outside of Cambodia, have initiated future distribution and public relations networks, which will facilitate smoother alpha testing, beta testing, and final release.

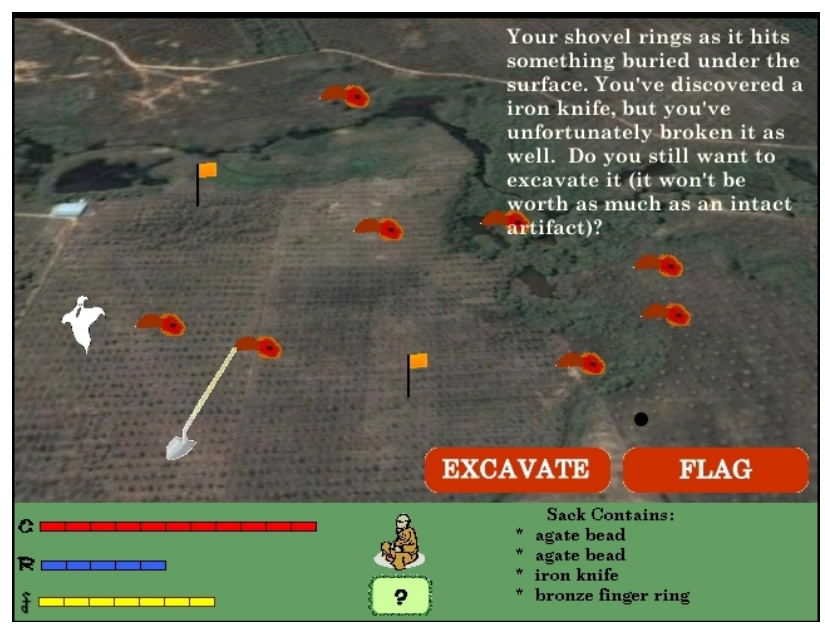

Figure 6. Screen shot of first level game play from the proof-ofconcept prototype. Graphics, artwork and icons are stand-ins for those being created for the final game (Courtesy of the author).

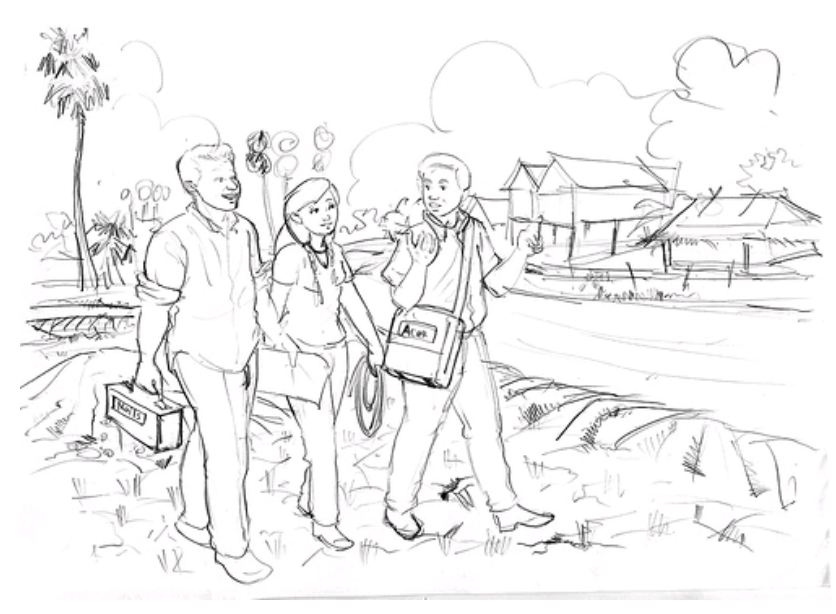

Figure 7. Rough sketch of a scene from the introductory sequence-Western and Khmer archaeologists walk to a newly discovered archaeological site. Copyright Our Books (Sangsalapak).

Looter! follows the story of Samnang, a Khmer youth coerced into looting by a smuggling middleman, who, as 
the story unfolds, learns just how difficult and dangerous this occupation is. Looter! will expand this message (the gist of the Wrath of the Phantom Army story) into an interactive learning experience. An animated introduction will immerse players within an Iron Age (c. AD 500) Khmer village to experience the daily life of its inhabitants, as revealed by textual and visual representations of discoveries at an in-game excavation (Fig. 7). As the animation morphs into modern times, players see that the excavation area is being perused by a "shady looking" character.

Looter! will be a Flash based game incorporating English and Khmer text, animation, drawings, photos, music, sound effects, an aerial view and scrollable corner map. In level one, you play as Samnang, looking to help support his family. Falling in with Mr. Gark (the middleman), the player will learn how looters work, gain a basic knowledge of prehistoric Cambodian artefacts, and experience looting's considerable risks: breaking laws, ruining artefacts, getting cheated, and enduring community ire. One does not have to indiscriminately loot, however. Using pin flags stolen from a nearby archaeologist's field camp, players can choose to mark discoveries, a practice that can help waylay authorities. If one disturbs a skeleton in search of rarer artefacts, they will raise an angry ghost, which ends the game if one's cursor collides with it. A monk can be called upon to banish the spirits, but since your loot reveals your illicit activities, he will only help you once. If players can earn enough money, they will seemingly win and be offered their own antiquities stall in Bangkok ... only to be caught in a sting operation. This occasional real-world outcome will only increase with further awareness on behalf of the public and local authorities. If too much damage is done, to the landscape or the community's reputation, the avatar will be cast out from his village. Thus, the only way to progress is for the player to exercise enough balance during play that players come to understand the consequences/difficulties of looting and benefits of conservation. Accordingly, the game's archaeologists will notice the avatar, acknowledge his plight, and introduce the next level.

In level 2, players (through Samnang) will have a new job; that of archaeologist-in-training. They must help archaeologists stop looting at a newly discovered site by directing heritage police toward looters. If all looting is curtailed in time, points are calculated, and the player is faced with numerous exposed graves with specific amounts of recoverable archaeological information, indicated by individual "damage" meters. Instructions will explain the available archaeological techniques and equipment a player can utilize, and by appropriately deploying these tools, players earn additional points. As players salvage information and store it as field notes (using an in-game notebook), they will be able to generate new end-game scenarios by presenting their findings (through simulated text-based negotiation sessions) to avatars representing various cultural heritage stakeholders (e.g., tourists, museum officials, villagers), programmed to respond differently depending on the information and level of detail a player presents them with. Players will also be able to document, via their own real-world photos or written observations storable on an affiliated web site and discussion forum, the trade in prehistoric Khmer artefacts observable wherever they might be playing. First-time players can choose to create a username and password linked to a folder into which their data can be uploaded, and updated, by date and location. While not required to complete the game, joining this online community will provide the player with additional in-game "field notes" to use, thereby affecting their outcome. Alpha and beta testing will involve both English and Khmer play-testers and, following the game's release, attitude assessment surveys will be conducted and the ongoing aspects of the project will be altered and refined accordingly, as game play and database creation are continuously monitored.

\section{REPLAY VALUE: ONGOING DEVELOPMENT AND PLANNED USE}

Development of several key aspects of the final game is currently underway. Colleagues within Cambodia have begun to create the two-dimensional background artwork, to be animated later, which will underpin the introductory, interstitial, and end-game cut scenes. Furthermore, colleagues in the United States have also begun work on sound effects and the conversion of the original Director prototype into Flash, which will serve as the foundation upon which continued game construction can occur. At the present time, development and testing is planned to be finished by 2010, with full incorporation into larger outreach programs, and the creation of playable versions using non-PC technologies, simultaneously. Overall, we will disseminate this learning tool via numerous small and large scale platforms, as well as incorporate it into school curricula (see below, also O’Reilly and Patterson 2009). In addition to the web-delivered online version of the game, a mobile phone and interactive DVD menu (Fig. 8)

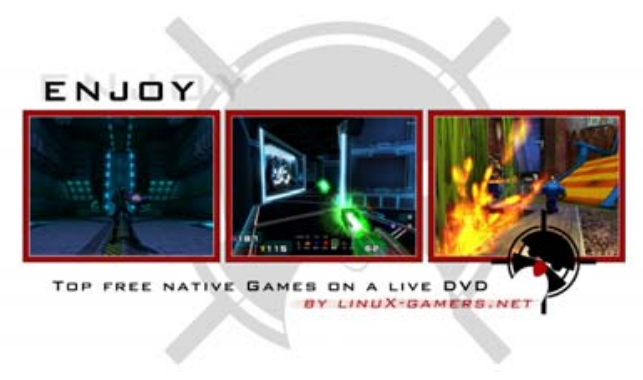

Figure 8. 'Wall paper' example of graphical quality possible in DVD menu games. http://live.linuxgamers.net/content/home_images/dvd-shot.png. (Courtesy of LinuX-gamers.net)

version will also be created, both available in Khmer and English. Computer use throughout Cambodia is expanding, and cell phone and DVD use is ubiquitous even in rural areas, both crucial factors in the decision to create an 
engaging, multimedia heritage conservation project. The "many-to-many" nature of cell phone and DVD use also ensures that the game and its message can be quickly shared and discussed amongst users, and from the production end, it is now relatively straightforward to transfer a Flash based computer game onto other technological media. In remote villages, where computer access still remains low and incidences of looting are high, Looter! will compliment the verbal and written outreach efforts discussed above.

The Looter! project, in conjunction with Heritage Watch, also seeks to convey a heritage conservation message to Cambodia's adolescents, many of whom live in villages frequented by middlemen. With Ministry of Education support, the Heritage for Kids program seeks to incorporate lessons in archaeology and heritage preservation into the national curriculum. The inclusion of Looter! will compliment verbal and written instruction on these topics, exposing them to the importance of, and threats to, archaeological sites. Looter! will fill a void in current youth-oriented outreach efforts, namely a lack of engaging new media activities. The in-game option allowing players to document observations of antiquities selling in their areas will be simple enough for all but the very young, and will simultaneously create a near real-time database, support use of the anti-looting hot-line, and provide in-country authorities with accurate data on demand and fluctuation in the types and quantities of artefacts reaching urban markets. The nature of this ingame option means that the more a player uses it, the better their second-level outcome, and the more that looting and the antiquities trade can be monitored and curbed.

\section{CONCLUSION}

The goals of this paper have been to explain the "realworld" necessity and urgent need to push forward on new and diverse archaeological education and outreach projects, especially those utilizing interactive, multi-media methodologies, such as educational computer games, and ground such innovations in appropriate theoretical and contextual frameworks. Given the fact that "there is clear evidence that the major threat to Cambodia's heritage now comes from semi-professional looters, motivated by poverty to supplement their incomes," and that sites being actively destroyed are, in general, "not documented and represent a rich archaeological resource that has not been studied in any meaningful way” (O’Reilly 2007), it is imperative that all possible countermeasures are taken. The design approach of the game as currently planned will facilitate its ready adoption into broad-scale conservation endeavours by making Looter! available in multiple, location-appropriate technological media. This will ensure that populations traditionally responsible for both supply and demand can educate themselves about the entire process of looting, and one's potential role in it should one choose to loot or purchase antiquities, through the eyes of an avatar representing those whom looting effects most; the rural Khmer poor. Furthermore, incorpo- ration and use of the on-line antiquities trade database will hopefully foster a sense of active, shared control amongst players over the fate of Cambodia's irreplaceable heritage. While it is possible that this in-game option will be underutilized or technical difficulties will ensue in development or dissemination, they are worth working through, as time is of the essence and the threat remains tangible.

\section{REFERENCES}

Anon. 1992. Gecko Column. Phnom Penh Post. Phnom Penh.

Anon. 2005. Antiquities to grow old with. September 26, 2005. Business Week. McGraw-Hill.

Abt, C.C. 1970. Serious Games. New York: Viking Press.

Albrecht, G. et al. 2001. Circular earthworks Krek 62/52: recent research on the prehistory of Cambodia. Asian Perspectives 39:20-46.

Albrecht, G. 2007. New Iron Age cemetery discovered, immediately looted. http://memotcentre.org/News.html.

Baugh, M. 2007. Antiquities: the hottest investment. December, 12, 2007. Time Magazine.

Bogost, I. 2007. Persuasive Games. Cambridge, Mass: MIT Press

Brodie, N. \& Luke, C. 2006. Conclusions: the social and cultural contexts of collecting. In N. Brodie, M. M. Kersel, C. Luke and K.W. Tubb (eds.), Archaeology, Cultural Heritage, and the Antiquities Trade, pp.303-319. Gainesville: University Press of Florida.

Carbonel, J. P. \& Guth, C. 1968. Le gisement Pleistocene inferieur du Phnom Loang (Cambodge), stratigraphie et faune. Comtes Rendus de L'Academie des Sciences 267, Serie D: 2,077-2,080.

Chandara, L. 2007. Gold digging villagers search KR gravesite. May 8, 2007. Cambodia Daily: Phnom Penh.

Chaumeau, C. 1997. Biggest Angkor loot haul seized after stand-off. February 21, 1997. Phnom Penh Post: Phom Penh.

Chhem, R.K. et al. 2004. Multislice computed tomography of two 2000-year-old skeletons in a soil matrix from Angkor, Cambodia. Canadian Association of Radiology Journal 55:235-241.

Clayton, T. 1998. Building the new Cambodia: education destruction and construction under the Khmer Rouge, 1975-1979. History of Education Quarterly 38:1-16.

Consalvo, M. 2003. Hot dates and fairy-tale romances: studying sexuality in video games. In Wolf, M.J.P. and Perron, B. (eds.), The Video Game Theory Reader, pp. 171-194. New York: Routledge.

Cordova-Gonzalez, J. 2000. Teaching archaeology at the Museum San Miguel de Azapa in northernmost Chile. In McManamon, F.P. and Hatton, A. (eds.), Cultural Resource Management in Contemporary Society: Perspectives on Presenting and Managing the Past, pp. 319-325. New York: Routledge.

Dega, M. 1999. Circular settlements within eastern Cambodia. Bulletin of the Indo-Pacific Prehistory Association 2: 181190.

Dega, M. 2002. Prehistoric Circular Earthworks of Cambodia, Oxford: Archaeopress. 
Dowling, N.H. 1999. A new date for the Phnom Da images and its implications for early Cambodia. Asian Perspectives 38:51-61.

Gee, J. P. 2003. What video games have to teach us about learning and literacy. New York:Palgrave Macmillan

Heritage Watch 2006. An Archaelogical Survey of the Area Surrounding Thmar Puok, Banteay Meanchey, Cambodia. Phnom Penh: Heritage Watch.

Heritage Watch 2008. New weapon to fight theft of Khmer relics http://www.heritagewatch.org/hnews.php?theId=59.

Higham, C.F.W. 2002. Early Cultures of Mainland Southeast Asia. Bangkok: River Books.

Huitzinga, J. 1955. Homo ludens. New York: Beacon.

International Council of Museums 2007. The "One Hundred Missing Objects” Series.

http://icom.museophile.sbu.ac.uk/list_thanks_angkor.html

Jennings, J. \& Rand, C. 2008. Stemming the tide: how social marketers can help in the fight against looted antiquities. The SAA Archaeological Record 8:28-31.

Knoll, P. C. (ed.). 1990. Listing of Education in Archaeological Programs: the LEAP Clearinghouse, 1987-1989 Summary Report. Washington, D.C.: National Park, U.S. Department of the Interior.

Levy, P. 1943. Recherches Prehistoriques dans la Region Mlu Prei. Hanoi: Publication de l'Ecole Francaise d'Extreme Orient. (In French).

Lidington, H. 2002. The role of the internet in removing the 'shackles of the salesroom': anytime, anyplace, anything, anywhere. Public Archaeology 2:67-84.

Loftus, G. R. and Loftus E. F. 1983. Mind at Play: The Psychology of Video Games. New York: Basic Books.

Lor, C. 2007. Villagers take up KR killing field treasure hunt. May 10, 2007. Cambodia Daily: Phnom Penh.

Ly, V. 1999. Samrong Sen; Early Workshop of Material Culture in the Flooded Area of the Tonle Sap River, Kompong Chhnang, Cambodia. Unpublished $\mathrm{PhD}$ dissertation, Sophia University, Tokyo.

Mansuy, H. 1902. Stations Prehistoriques de Somron-Sen et de Longprao (Cambodge). Hanoi: F. N. Scheider. (In French).

Matsuda, D. 1998. Subsistence Digging in and Around Belize. Cincinnati: The Union Institute.

Miller, J. C. \& Pitaluga, P. 2000. Cultural marketing and archaeology: the case of Brazil. Journal of Nonprofit \& Public Sector Marketing 8: 63-74.

Moe, J. 2000. America's archaeological heritage: protection through education. In McManamon, F.P. and Hatton, A. (eds.), Cultural Resource Management in Contemporary Society: Perspectives on Presenting and Managing the Past, pp. 276-288. New York: Routledge.

Mourer, R. 1977. Laang Spean and the prehistory of Cambodia. Modern Quaternary Research in Southeast Asia 3: 29-56.

Net, K. 1994. Head of statue lost from Phnom Chisor. Reaksmei Kampuchia: Phnom Penh.

O’Reilly, D. 2007. Shifting trends of heritage destruction in Cambodia: from temples to tombs. Historic Environment 20:12-16.

O’Reilly, D. and Patterson, G. 2009. The tide is turning: battling heritage destruction in Cambodia through social market- ing and education. The SAA Archaeological Record 9: 1114.

O'Reilly, D. and Sytha, P. 2001. Recent excavations in Northwest Cambodia. Antiquity 75:265-266.

O’Reilly, D., von den Driesch, A. and Vouen, V. 2006. Archaeology and archaeozoology of Phum Snay: a late prehistoric cemetery in northwestern Cambodia. Asian Perspectives 45:188-211.

Parkes, S., McAnany, P. and Murata, S. 2006. The conservation of Maya cultural heritage: searching for solutions in a troubled region. Journal of Field Archaeology 31:425432.

Politis, K.D. 2002. Dealing with the dealers and tomb robbers: the realities of the archaeology of the Ghor es-Safi in Jordan. In Brodie, N. and Tubb, K.W. (eds.), Illicit Antiquities: The Theft of Culture and the Extinction of Archaeology, pp. 257-268. New York: Routledge.

Prensky, M. 2001. Digital Game-Based Learning. New York: McGraw-Hill Press.

Renfrew, C. 2000. Loot, Legitimacy, and Ownership: the Ethical Crisis in Archaeology (Duckworth Debates in Archaeology). London: Duckworth Press.

Reyes, D. and Lopez, R. 2008. 4 Southland museums raided in looting probe. January 25, 2008. Los Angeles Times (Online). http://articles.latimes.com/2008/jan/25/local/memuseums25.

Ruggill, J. and McAllister, K. 2008. Fluency in Play: Computer Game Design for Less Commonly Taught Language Pedagogy. Tucson: Center for Educational Resources in Culture, Language, and Literacy.

Shoup, D. and Monteiro, L. 2008. When past and present collide: the ethics of archaeological stewardship. Current Anthropology 49:328-333.

Sophady, H. 2002. Recent excavations at a circular earthwork site, Krek, Cambodia. Bulletin of the Indo-Pacific Prehistory Association 20: 395-420.

Stark, M.T. 2004. Pre-Angkorian and Angkorian Cambodia. In Glover, I. and Bellwood, P. (eds.), Southeast Asia: From Prehistory to History, pp. 89-120. New York: Routledge.

Stark, M.T. and Griffin, B. 2004. Archaeological research and cultural heritage management in Cambodia's Mekong Delta: The search for the "Cradle of Khmer Civilization." In Rowan, Y. and Baram, U. (eds.), Marketing Heritage: Archaeology and Consumption of the Past, pp. 117-141. Walnut Creek: Altamira Press.

Stark, M.T. 1998. The transition to history in the Mekong Delta: a view from Cambodia. International Journal of Historical Archaeology 2:175-203.

Stone, P.G. and Molyneaux, B.G. (eds.). 1994. The Presented Past: Heritage, Museums, and Education. New York: Routledge.

Sutton-Smith, B. 2001. The Ambiguity of Play. Cambridge, Mass.: Harvard University Press.

Thosarat, R. 2001. The destruction of the cultural heritage of Thailand and Cambodia. In Brodie, N., Doole, J. and Renfrew, C. (eds.), Trade in Illicit Antiquities: the Destruction of the World's Archaeological Heritage, pp. 7-18. Cambridge, UK: Cambridge University Press. 